\title{
PREVOCATIONAL TRAINING AND EDUCATION OF STUDENTS WITH SPECIAL EDUCATIONAL NEEDS IN INTEGRATED ENVIRONMENT
}

\author{
Ingrida Baranauskienè \\ Milda Jankutè \\ Šiauliai University, Lithuania
}

\begin{abstract}
Prevocational training and education in integrated environment is especially important for students with special educational needs because it gives them possibility to avoid social exclusion and discrimination in the labour market. In the present article the possibilities of prevocational training and education of students having special educational needs in integrated environment have been analyzed. Specialists' attitude towards prevocational training and education of students having special educational needs in integrated environment has been revealed; it has been found out how prevocational training and education is performed; factors influencing effective prevocational training and education have been investigated.
\end{abstract}

Key words: integrated environment, prevocational education, prevocational training, students with special educational needs.

\section{Introduction}

Problems and relevance of the research. Already in basic school a young person faces the intentions of vocational choice and the search for possibilities of their realization. In a young person's life prevocational education becomes especially important. In order to appropriately create and develop common system of vocational counselling (vocational informing, vocational counselling, development of career planning skills) in Lithuania, an especially important role should be given to prevocational education and rendering vocational counselling services for students who study at mainstream schools. R. Laužackas (2006) defines prevocational education as the first stage of vocational training. At this time the influence and support from family, schoolmates, teachers, social pedagogues, vocational counsellors, and psychologists becomes very important and relevant. The most important thing is to organize prevocational education so that important factors from the aspect of student's vocational development interests, inclinations, values, abilities, knowledge, personal competences and the requirements from the world of work - constantly become clear to a student (Barkauskaite, 2007). Prevocational training and education in integrated environment is especially important for students with special educational needs. According to Baranauskienè, Radzevičienè and Valaikienė (2012), purposeful system of vocational counselling would help students with special educational needs to reach not only primary but also secondary or tertiary level of vocational education. 
Nowadays not enough attention is paid to prevocational training of students with special educational needs, teaching often does not meet the demands of business and labour market, little attention is paid to the development of students' entrepreneurship. Young people with special educational needs still face the difficulties of adaptation in the labour market and social life. The issue of vocational purposefulness of people with special educational needs is becoming especially relevant and important.

Aim of the research - to assess the situation of prevocational training and education of students with special educational needs in integrated environment. Object of the research. Prevocational training and education in integrated environment in Lithuania.

Sample of the research. The sample of the research consists of 226 specialists (pedagogues, special pedagogues, social pedagogues, vocational counsellors, vice principals) from all over Lithuania, selecting institutions using the method of convenience sampling.

\section{Methods, methodology and organization of the research}

Empirical research has been performed using qualitative approach. Qualitative approach of the analysis is closer to the aspirations of the present research because it creates the possibility to investigate the quality of prevocational training and education rendered by institutions in integrated environment not overestimating quantitative indicators. The method of content analysis of nonstandardized material has been used that was applied according to methodological grounded theory described by Strauss, Corbin (Страусc, Корбин, 2001).

The elements of action research have also been used. In case of the present research by trainings it has been attempted to change specialists' attitude towards students with special educational needs from the aspect of prevocational training and education in integrated environment. During the national project there were trainings on the topic "Possibilities of prevocational training for students with special educational needs". Organization of the services of vocational counselling requires training of staff working at school including inservice training, preparation of methodical material and other measures necessary for vocational counselling, integration of career planning issues into the content of education, creation of the infrastructure of vocational counselling services (Baranauskiene, Valaikienè, 2010).

The data have been categorized according to semantic relations and graphically presented using Microsoft Office Excel programme. Ensuring of the reliability of the data is related to the results of the research of content analysis. The control of intersubjectivity of the research has been performed using the method of experts. 


\section{Results of the research}

Characteristics of the sample of the research. In order to reveal the possibilities of prevocational training and education of students with SEN in integrated environment 226 specialists (pedagogues, special pedagogues, social pedagogues, vocational counsellors, vice principals) have been interviewed. Performing the research the information about demographical situation of the respondents (i.e. gender, type of school they work in, position, age, work experience) has been collected. Out of all the respondents 214 were female, $12-$ male. The majority of the respondents work in basic school. According to the position the majority of the respondents were language teachers. The majority of the respondents belong to the age group from 36 to 56 years. The smallest part of the respondents belongs to the age group from 57 to 74 years. More detailed distribution of the respondents according to age has been presented in Figure 1.

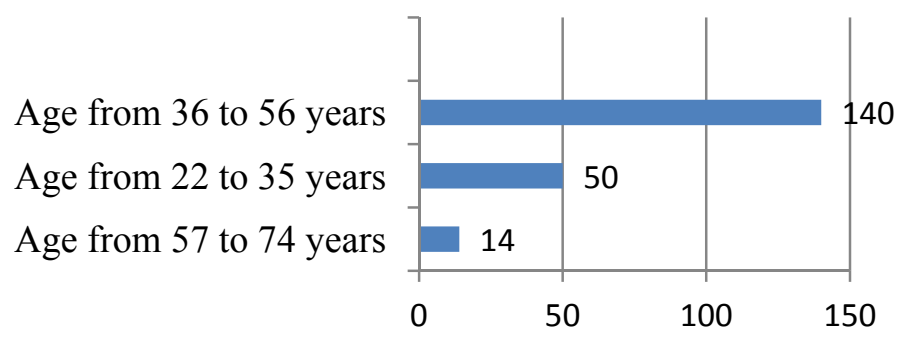

Figure 1 Distribution of the respondents according to age

According to work experience the majority of the respondents are assigned to the group from 16 to 26 years, the smallest number is from 36 to 46 years. It has been reflected in Figure 2.

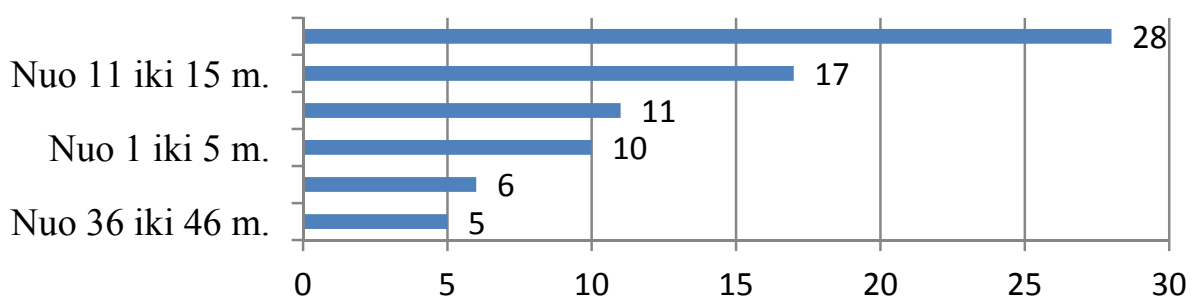

Figure 2 Distribution of the respondents according to work experience

Analysis of prevocational training and education in integrated environment of students with special educational needs. Baranauskienè and Valaikienè (2012) 
state that well considered social policy and prevocational training at schools directed towards the development of general and special abilities of students with SEN could help to ensure successful integration of people with disabilities in the labour market and wider social participation in societal activity.

During the research it has been found out that in the majority of schools there are indicators that vocational training for students having special educational needs exists (Figure 3). It becomes clear in the biggest category There are indicators that vocational training at school is organized (91 statement, e.g.: This process takes place at school; Prevocational training is organized). The category Prevocational training does not take place (15 statements, e.g.: It does not take place, students with special needs are left aside; prevocational training does not take place at school) reflects the fact that school community is not interested in the aspect of prevocational training of students. The last category is Clear indicators of the organization of prevocational training dominate (9 statements, e.g.: Prevocational training at school is actively rendered; Prevocational training at school take place according to the plan created in advance). Only the small part of the respondents stated that prevocational training is rendered appropriately.

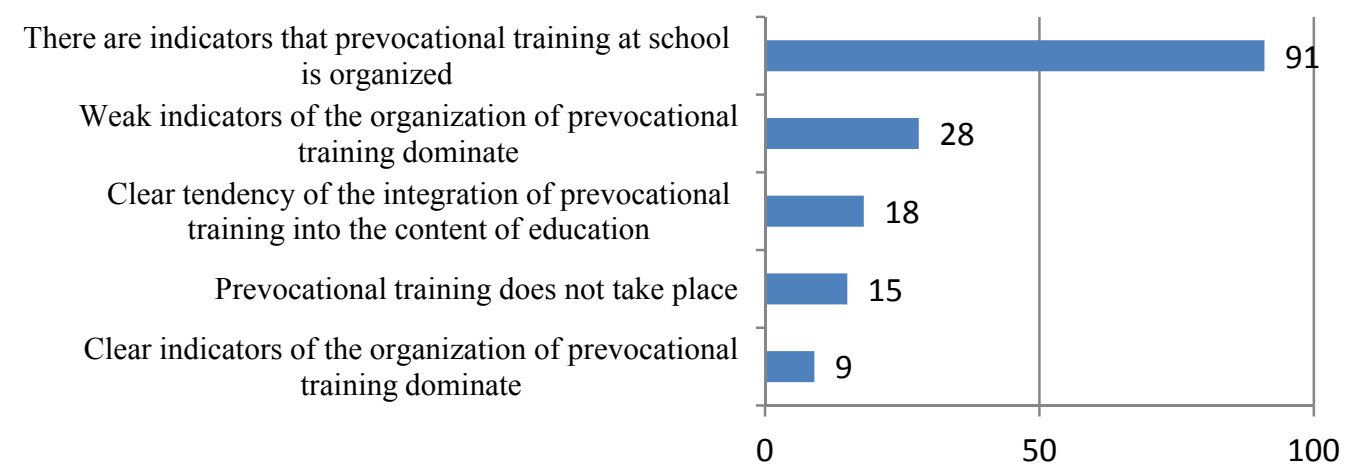

Figure 3 Rendering prevocational training at school

The results of the research have revealed the difficulties that interfere with appropriate and effective rendering of prevocational training (Figure 4). The respondents named the lack of finances as the most relevant problem that causes difficulties in rendering prevocational training. The biggest category is Insufficient financing (14 statements, e.g.: There is no financing, equal work is rendered to everyone according to possibilities; Getting little financing at school it is difficult to render prevocational training). Only a small part of the respondents stated that poor motivation of students and pedagogues and insufficient competence of pedagogues has negative influence on appropriate rendering of prevocational training. 


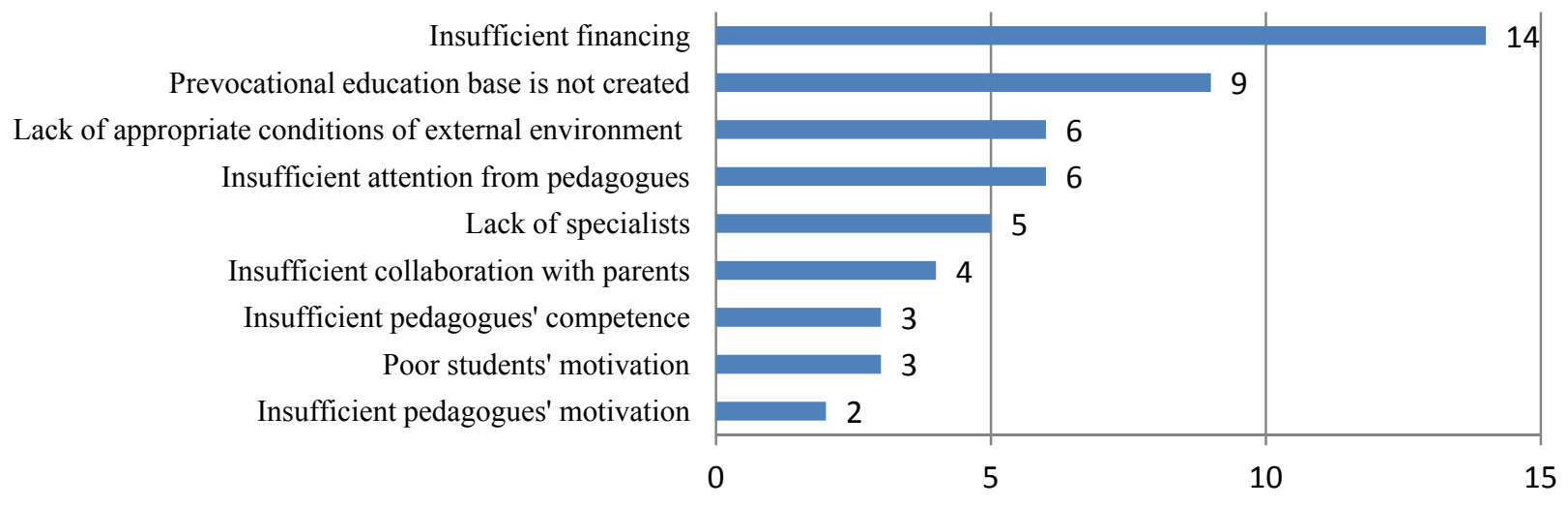

Figure 4 Difficulties that interfere with rendering of prevocational training

Organization of prevocational education of students with special needs should be performed in two directions: development of general abilities and special, relatively "vocational", abilities. Families of students with special needs should be involved in the process of prevocational training, certain new subjects related to prevocational training should be implemented in the content of education, individualized students' practical probation of professions, development of the concept of entrepreneurship, orientation towards the concepts of enablement, the paradigm of social participation and progressivism education (Baranauskiené, Valaikienè, 2010) (cit. Baranauskiené, Valaikienè, 2012).

The ways, with the help of which schools organize prevocational training have been investigated. Many various ways that create conditions for the organization of prevocational training have been mentioned (Figure 5). The biggest category is Visits to Vocational Training Centre and other educational institutions (39 statements, e.g.: Students meet the staff of VTC, The school collaborates with vocational schools, the treaties are signed). 


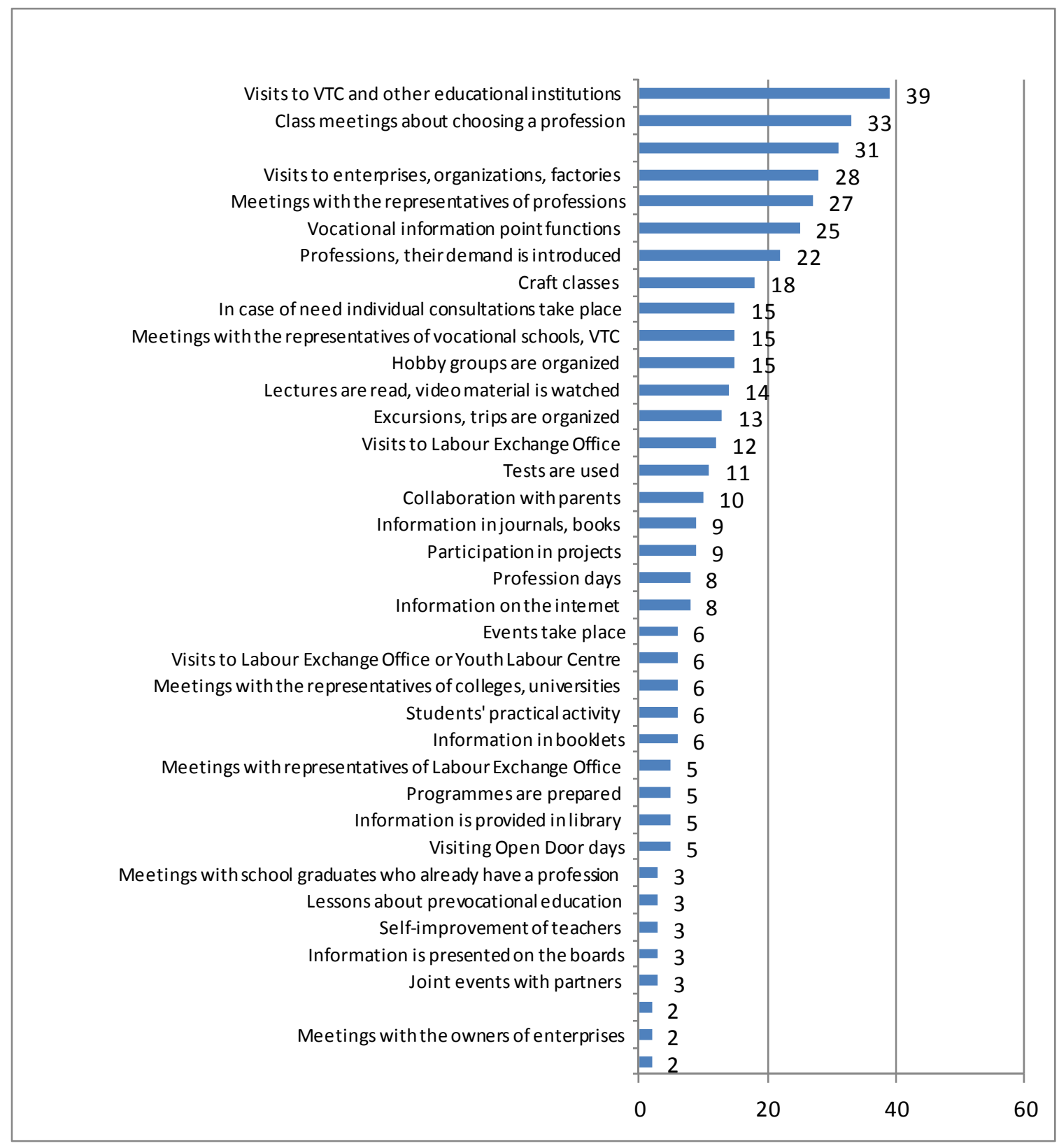

Figure 5 Forms of the organization of prevocational training

According to Baranauskienè, Juodraitis (2008), family directly and indirectly contributes to the choice of profession because it is in family where role models are presented, experience is accumulated and possibilities are foreseen, certain value system is implemented. It is reflected in the category Highlighting the role of family (67 statements, e.g.: Parents' role should be the most important because they should encourage students to participate in this activity, The role of family is very important). Quite big part of the respondents stated that students' parents lack interest in the process of child's choosing a profession. It is proved by the category Insufficient participation of family (38 statements, e.g.: The role of family in the process of child's education is very little; parents do not show initiative in communicating with pedagogues). 


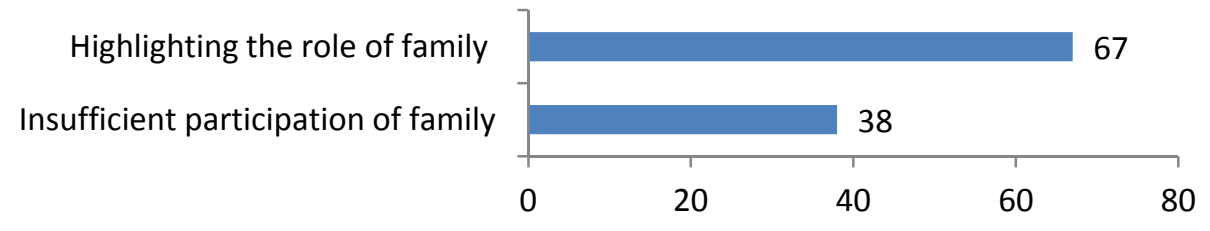

Figure 6 Role of family in the process of prevocational training

Practical probation of the abilities of students with SEN is important in choosing a profession corresponding to students' fields of interests because sometimes students with SEN inadequately assess their possibilities of choosing a profession (Baranauskiene, Valaikienè, 2012). From the obtained results of the research it can be seen that the majority of the pedagogues state that students do not have possibility of practical probation of professions. It is reflected in the biggest category Conditions are not created (50 statements, e.g.: There are no possibilities to practically get acquainted with the profession; There is no possibility to test professions at school). Only a very small part of the respondents mentioned that students are given versatile conditions of practical probation of professions.

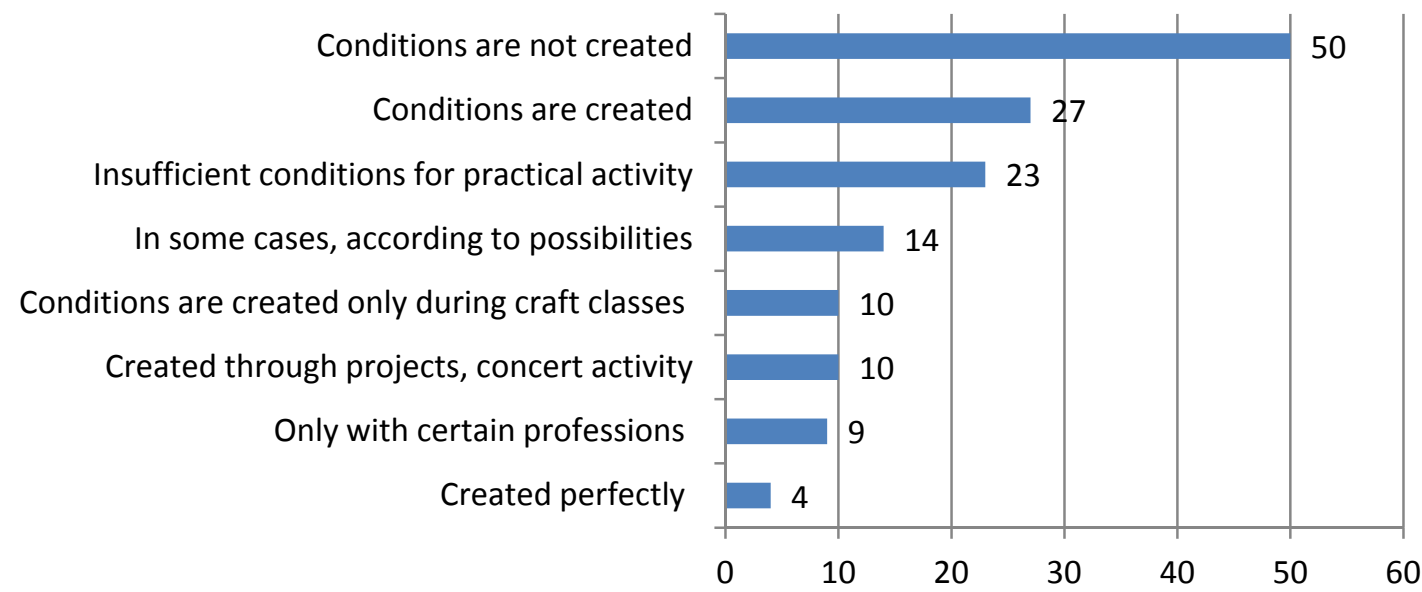

Figure 7 Possibility to practically test professions

The results of the research reveal that pedagogues acknowledge prevocational training as a very important factor in the process of students' choosing a profession. It is proved by the category Importance of prevocational training is acknowledged (94 statements, e.g.: Prevocational training is necessary, The importance of prevocational training in the process of education is big). Only a small part of the respondents named prevocational training as not important. The results are reflected in the category Is not important (2 statements, e.g.: 
Prevocational training in the process of education is not as important as other subjects, Prevocational training is not important).

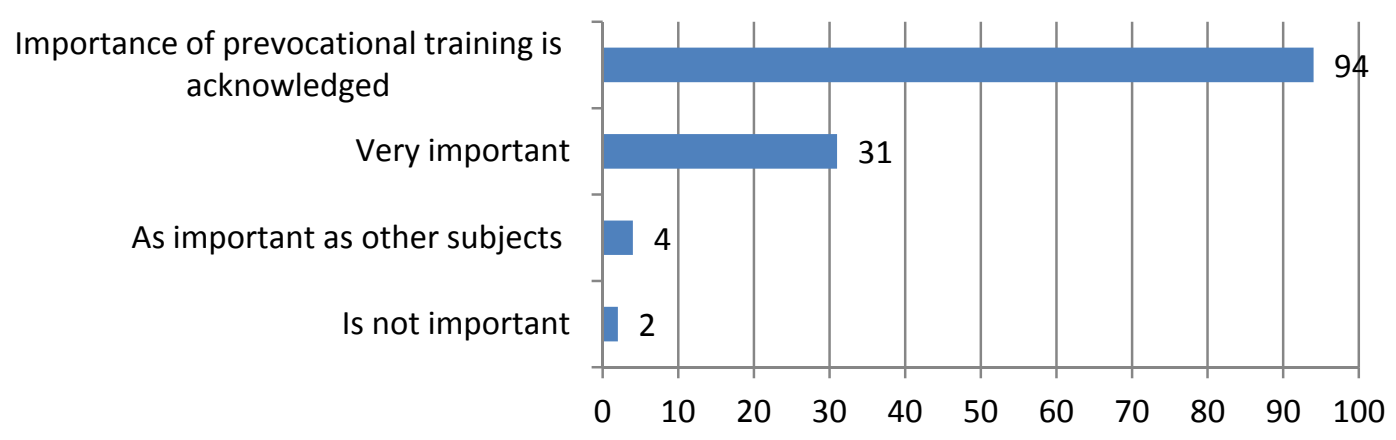

Figure 8 Importance of prevocational training in the process of education

Teachers should be able to assess students' special needs, to respectively adapt curricula and to train children's abilities with various auxiliary aids (Samsoniene, 2006). It has been investigated whether pedagogues have experience in working with students having special educational needs. The majority of the respondents stated that they do not have such kind of experience. It has become clear in the category Do not have experience $(75$ statements, e.g.: Do not have experience in organizing education for students with SEN; Do not have experience). The category Have experience (64 statements, e.g.: Have experience in organizing vocational counselling for students having SEN; have experience). More detailed information has been presented in Figure 9.

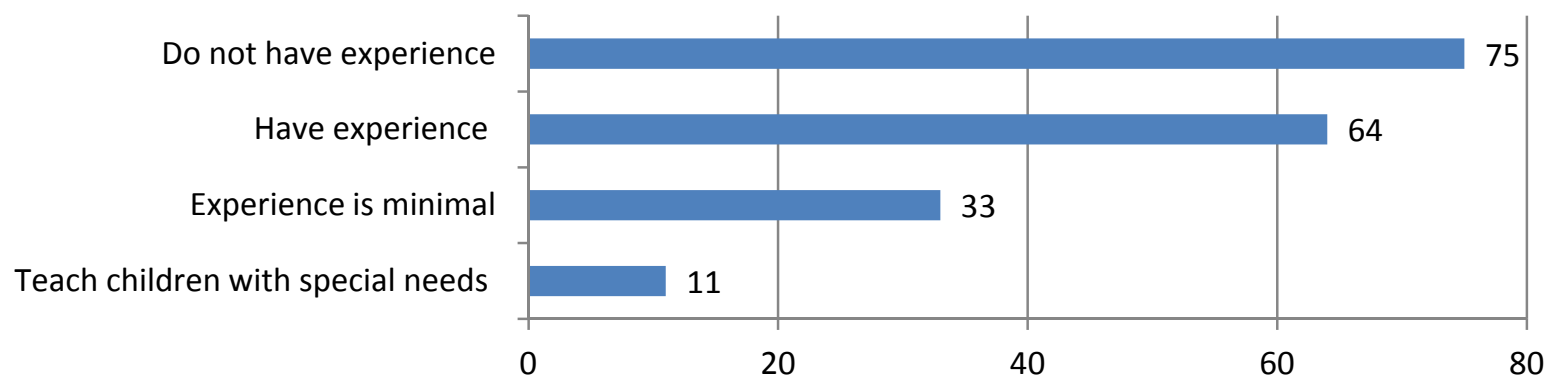

Figure 9 Pedagogues' experience in working with students having SEN

After the trainings of the national project on the topic "Possibilities of prevocational training for students with special educational needs" the participants of the training were asked what factors influence successful and 
effective prevocational training. The categories Child's motivation (58 statements, e.g.: The most important principles of success in prevocational training is the wish of students themselves; Students' wish to strive for their dreams) and Good base (56 statements, e.g.: Material base; Variety of learning material and ways) gathered almost equal number of statements. Collaboration with social partners, integration into lessons and appropriately chosen activities are the least accentuated. More detailed information has been presented in Figure 10.

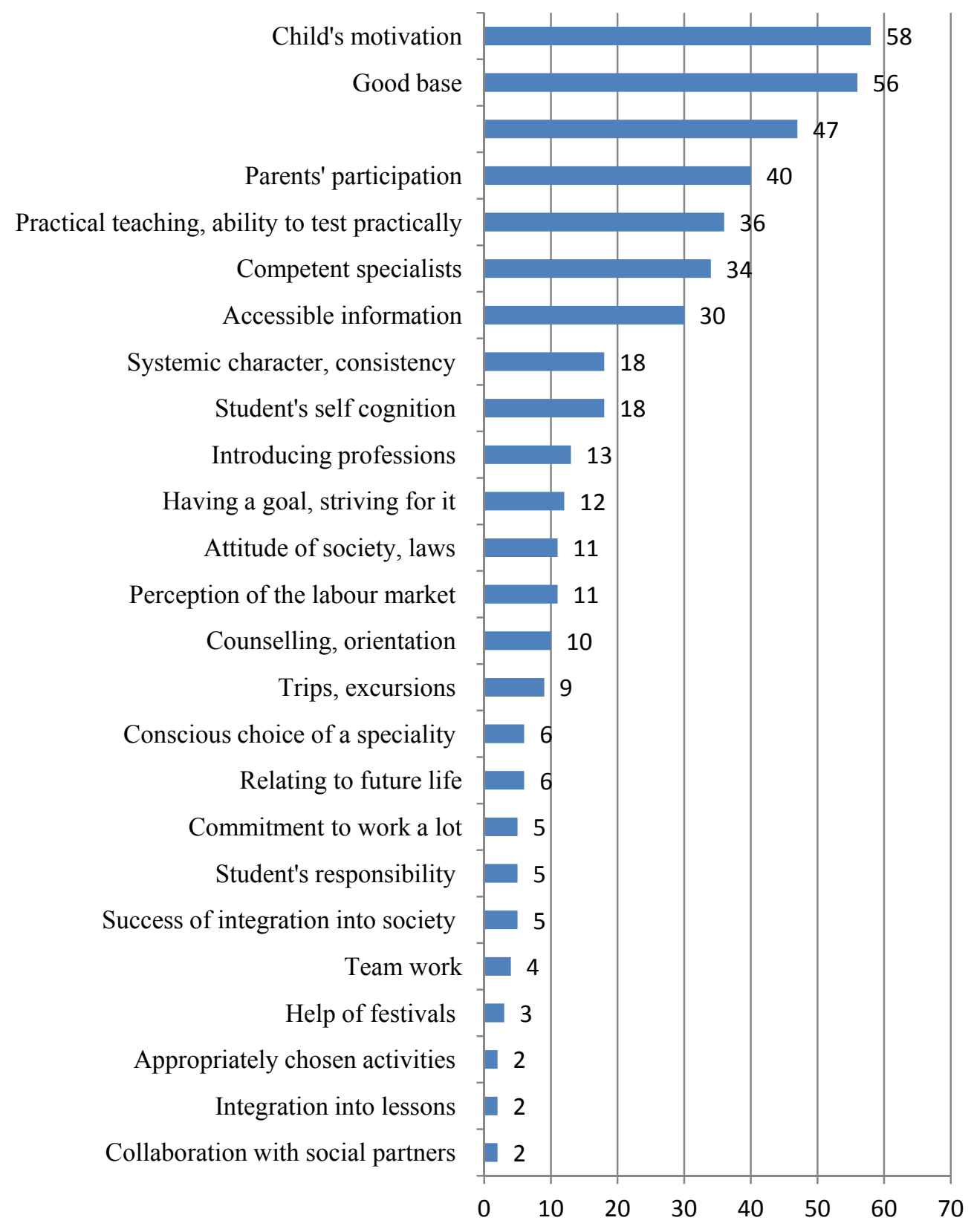

Figure 10 Principles of the success of prevocational training 


\section{Conclusions}

1. Although the data of the research have revealed that in majority of schools prevocational training and education for students with special educational needs is performed, however, to perform it primitive ways are used that have minimal influence on students' resolution in the aspect of choosing a profession.

- The main forms of the organization of prevocational training are visits to VTC and other educational institutions, class meetings on choosing a profession, conversations and consultations with responsible school pedagogues about choosing a profession, meetings with the representatives of professions.

- During the research the problems that interfere with appropriate rendering of prevocational training and education have become clear. It is insufficient pedagogues' motivation, poor students' motivation, insufficient pedagogues' competence, insufficient communication with parents, lack of specialists, unsuitable conditions of external environment, insufficient attention form pedagogues, not created base of prevocational education, insufficient financing.

2. The results of the research have shown that in the opinion of the majority of the respondents, prevocational training is an especially important factor in the process of education, the success of which is conditioned by staff's preparedness to work with students having SEN, setting aims of prevocational training and education and application of suitable methods to achieve these aims.

3. The respondents' answers after the trainings have revealed that specialists perceive the importance of prevocational training and education, their attitude in this aspect has become more positive, therefore, trainings should be continued because they have positive influence on the quality of the process of prevocational training and education.

\section{Bibliography}

1. Baranauskienè, I., Juodraitis, A. (2008 a). Neigaliuju profesinè reabilitacija: sèkmès prielaidos. Šiauliai: Všı̨ Šiaulių universiteto leidykla.

2. Baranauskienè, I., Radzevičienė, L., Valaikienè A., (2012 b). Vocational counselling for children and youth with special educational needs : parameters of the ideal model : scientific study. The Methods for Research of Vocational Counselling for Children \& Youth with Special Educational Needs (Recommended Guidelines). Kraków : Wydawnictwo Naukowe Uniwersytetu Pedagogicznego.

3. Baranauskienè, I., Valaikienè, A. (2012 c). Darbdavių požiūris ị mokinių, turinčiu specialiujų ugdymosi poreikių, dalyvavimą ikiprofesinio rengimo procese. PEDAGOGIKA (106). Vilnius: VPU. 
4. Barkauskaite, M., (2007). Profesinis konsultavimas ir orientavimas šiuolaikinio profesinio rengimo kontekste. Mokslo darbai (18). ACTA PAEDAGOGICA VILNESIA. Vilnius: Vilniaus univesiteto leidykla.

5. Страусс, А., Корбин, Ј., (2001). Основы качественного исследования: обоснованная теория, прочедуры и техника. Москва: УРСС, 2001.

6. Laužackas, R., (2005). Profesinio rengimo terminu aiškinamasis žodynas. Kaunas: „Morkūnas ir $\mathrm{KO}^{\prime \prime}$.

7. Samsonienè, L. (2006). Specialiuju poreikiu vaikai ir ju socialinè integracija. Vilnius: Vilniaus universitetas.

\begin{tabular}{|c|l|}
\hline Ingrida & Šiauliai University, \\
Baranauskienè & Faculty of Social Welfare and \\
& Disability Studies \\
& P. Višinskio str. 25, LT-76351 \\
& Šiauliai, Lithuania \\
& E-mail: i.baranauskiene@cr.su.lt \\
& Phone:+370 41 595730 \\
\hline Milda Jankutė & Šiauliai University, \\
& Faculty of Social Welfare and \\
& Disability Studies \\
& P.Višinskio str. 25, LT-76351 \\
& Šiauliai, Lithuania \\
& E-mail: sumc@cr.su.lt \\
& Phone:+370 41 595730 \\
\hline
\end{tabular}

